\title{
Peningkatan Hasil Belajar Peserta Didik pada Muatan IPA Melalui Metode Inquiry di Kelas VI SDN 155/X Kuala Dendang Semester Ganjil Tahun Ajaran 2021/2022
}

\author{
Agus Farichin \\ SDN SDN 155/X Kuala Dendang \\ J1. Unnamed Road, Rantau Indah, Dendang, Kabupaten Tanjung Jabung Timur \\ agus_farichin@gmail.com
}

\begin{abstract}
This study aims to describe and obtain information on improving science content learning outcomes through the Inquiry method. This research is a classroom action research which consists of two cycles, each cycle consists of two meetings. Each meeting consists of four stages, namely planning, implementation, observation and reflection. The subjects of this study were students of class VI SDN 155/X Kuala Dendang, totaling 8 people. This research was conducted in the odd semester of the 2021/2022 academic year. Data collection techniques using tests, observations, and documentation. Data were analyzed using percentages. The results showed that through the Inquiry method, it was possible to improve the learning outcomes of the sixth grade students of SDN 155/X Kuala Dendang science content.
\end{abstract}

Keywords: Science learning outcomes, Inquiry.

\begin{abstract}
Abstrak
Penelitian ini bertujuan untuk mendeskripsikan dan mendapatkan informasi peningkatan hasil belajar muatan IPA melalui metode Inquiry. Penelitian ini merupakan penelitian tindakan kelas yang terdiri dari dua siklus masing-masing siklus terdiri dari dua kali pertemuan. Masing-masing petemuan terdiri dari empat tahapan yaitu perencanaan, pelaksanaan, observasi dan refleksi. Subjek penelitian ini adalah peserta didik kelas VI SDN 155/X Kuala Dendang yang berjumlah 8 orang. Penelitian ini dilaksanakan pada semeseter ganjil tahun ajaran 2021/2022. Teknik pengumpulan data menggunakan tes, observasi, dan dokumentasi. Data dianalisis menggunakan persentase. Hasil penelitian menunjukkan bahwa melalui metode Inquiry dapat meningkatkan hasil belajar muatan IPA peserta didik kelas VI SDN 155/X Kuala Dendang.
\end{abstract}

Kata kunci: Hasil belajar IPA, Inquiry.

Copyright (c) 2022 Agus Farichin

Corresponding author: Agus Farichin

Email Address: agus_farichin@gmail.com (Jl.Unnamed Road, Rantau Indah, Tanjung Jabung Timur)

Received 10 January 2022, Accepted 20 January 2022, Published 16 Ferbuari 2022

\section{PENDAHULUAN}

Ilmu pengetahuan alam adalah suatu ilmu yang mempelajari alam beserta isinya yang meliputi semua mahluk hidup maupun benda mati. Ilmu Pengetahuan Alam mulai dipelajari oleh peserta didik semenjak mereka masuk Sekolah Dasar. Maka dalam pembelajarannya pun guru dituntut untuk dapat memotivasi peserta didik agar lebih mudah dalam menguasai Ilmu Pengetahuan Alam.

Namun kenyataannya yang sering kita temui dilapangan mata Pelajaran Ilmu Pengetahuan Alam menjadi mata pelajaran yang membosankan bagi peserta didik ini disebabkan oleh guru dalam membelajarkan Ilmu Pengetahuan Alam di kelas belum membuat materi pembelajaran jadi menarik karena tidak menggunakan media, penggunaan media yang kurang maksimal,sekolah belum memfasilitasi guru untuk dapat menggunakan media yang mendukung,misalnya penyediaan media yang sangat minim keberadaannya disekolah,bahkan guru belum sepenuhnya mengunakan media 
terutama media konkret, karena guru masih beranggapan bahwa penyediaan media konkret sangat rumit digunakan dalam pembelajaran Ilmu Pengetahuan Alam dan memerlukan waktu yang lama, akshirnya dalam pembelajaran Ilmu Pengetahuan Alam peserta didik kurang termotivasi dan kurang memahami konsep yang telah diberikan guru dan hasil belajar peserta didik masih di bawah rata-rata.

Padahal didalam pembelajaran Ilmu Pengetahuan Alam di kelas VI SD sangat butuh multimedia bahkan alat peraga yang bersifat konkrit. Dilihat dari kenyataan yang ada, yang menjadi penyebab terhalangnya ketercapaian pembelajaran Ilmu Pengetahuan Alam di kelas dapat dilihat dari beberapa indikasi, baik dari proses maupun capaian hasil belajarnya. Dari segi proses pembelajaran dapat diamati misalnya bagaimana peserta didik dapat menikmati pembelajaran sebagai suatu kegiatan yang menyenangkan. Artinya jika suatu pembelajaran tidak berhasil membangkitkan minat dan motivasi peserta didik untuk belajar secara menyenangkan, maka pembelajaran itu tidak dapat dikatakan efektif. Begitu juga dari segi hasil gejala ini dapat dilihat dari hasil ulangan harian peserta didik yang rendah pada pembelajaran Ilmu Pengetahuan Alam sebelumnya.

Peserta didik yang berada pada Sekolah Dasar (SD) berada pada rentangan usia 7-11 tahun. Pada usia tersebut seluruh aspek perkembangan tumbuh dan berkembang sangat luar biasa. Menurut Muhammad (2011:114) "kecendrungan berpikir anak usia Sekolah Dasar memiliki tiga ciri yakni: (1) berpikir konkrit yaitu peserta didik dihadapkan dengan keadaan dan peristiwa yang sebenarnya sehingga lebih nyata dan kebenarannya dapat dipertanggungjawabkan, (2) berpikir integratif yaitu memandang sesuatu yang dipelajari sebagai suatu keutuhan, (3) berpikir hierarkis yaitu dimulai dari yang hal-hal yang sederhana ke hal-hal yang kompleks '.

Menurut Piaget (dalam Rusman, 2010:251) "peserta didik pada usia SD (7-11 tahun) berada pada tahapan operasi konkret, peserta didik memandang segala sesuatu secara objektif dan berpikir secara operasional". Tahap operasi konkret, pola pikir peserta didik beranjak dari hal-hal yang nyata yaitu hal-hal yang dapat dilihat, diraba, dirasakan, didengar, dan dicium.

Pembelajaran di SD akan berhasil apabila guru memahami perkembangan intektual peserta didik usia SD berkisar pada 7-11 tahun. Seperti yang dinyatakan Piaget (dalam Arif, 2005:1), peserta didik dalam kelompok usia 7-11 tahun berada pada perkembangan intelektual pada tingkat operasional konkret, pada usia operasional konkret dicirikan dengan sistem pemikiran yang didasarkan pada aturan tertentu yang logis. Peserta didik pada masa operasinal konkret sangat membutuhkan benda-benda konkret untuk menolong perkembangan intelektualnya.

Tingkat perkembangan peserta didik pada usia SD melihat segala sesuatu sebagai satu keutuhan serta mampu memahami hubunganantara konsep secara sederhana. Proses pembelajaran masih bergantung kepada objek-objek konkrit dan pengalaman yang dialami secara langsung (Masnur, 2008:161). Pembelajaran hendaknya didesain sedemikian rupa sehingga hasil belajar yang diperoleh sesuai dengan harapan. Menurut Nana (2006:25) "hasil belajar adalah suatu akibat dari proses belajar dengan menggunakan alat pengukuran berupa tes yang disusun secara terencana, baik tertulis, tes lisan maupun perbuatan". menurut Oemar (2008:2) "hasil belajar adalah tingkah laku yang 
Peningkatan Hasil Belajar Peserta Didik pada Muatan IPA Melalui Metode Inquiry di Kelas VI SDN 155/X Kuala Dendang Semester Ganjil Tahun Ajaran 2021/2022, Agus Farichin

timbul dari yang tidak tahu menjadi tahu, timbul pertanyaan baru, perubahan dalam tahap kebiasaan keterampilan, kesanggupan menghargai, perkembangan sikap sosial, emosional dan pertumbuhan jasmani”.

Berdasarkan hasil pengamatan penulis di kelas VI pada semester I tahun ajaran 2021/2022 pembelajaran yang disajikan guru di kelas kurang menarik bagi peserta didik. Proses pembelajaran yang terjadi di kelas masih bersifat satu arah yaitu guru memberikan penjelasan di depan kelas dan peserta didik mendengarkan dan mencatat dengan baik apa yang disampaikan guru. Peserta didik terpaku dengan apa yang dijelaskan guru dan tidak mau mengemukakan ide-idenya bahkan cendrung diam jika diberi pertanyaan oleh guru.

Selama proses pembelajaran berlangsung peserta didik kurang aktif dan lebih banyak menunggu sajian dari guru. Pada saat pembelajaran berlangsung guru kurang memberikan kesempatan kepada peserta didik untuk berinteraksi antar sesama peserta didik atau dengan guru apalagi peserta didik dengan media. Guru kelas telah menggunakan bermacam model atau metode pembelajaran seperti ceramah, belajar kelompok, tanya jawab, dan penugasan yang dianggap bisa mengadakan perbaikan. Namun hasilnya masih belum sesuai dengan yang diharapkan. Konsep yang dikuasai peserta didik tetap tidak tertanam kuat dalam ingatannya. Hal ini dapat dilihat pada setiap ulangan harian, hasilnya masih di bawah Kriteria Ketuntasan Minimal (KKM) yang di tetapkan. Sebanyak 8 peserta didik di VI SDN 155/X Kuala Dendang dilakukan ulangan hanya 2 peserta didik yang mampu menguasai materi diatas KKM dengan kriteria ketuntasan $>75 \%$.

Mengatasi masalah yang dikemukakan di atas, guru harus mampu memilih metode pembelajaran yang tepat sehingga masalah tersebut dapat teratasi dengan baik. Diantara metode yang dapat diandalkan oleh seorang guru dalam proses pembelajaranadalah metode Inquiry dan eksperimen ditunjang dengan penggunaan alat peraga yang relevan dengan pembelajaran.

Metode Inquiry menuntut peserta didik untuk berfikir secara kritis, dan mampu memecahkan permasalahan serta mengambil keputusan secara objektif. Metode ini melibatkan peserta didik dalam kegiatan intelektual, agar kemampuan berpikir peserta didik berkembang secara optimal, sehingga pengalaman belajar menjadi bermakna dalam kehidupan nyata. Selain itu penggunaan metode Inquiry dapat menumbuhkan rasa ingin tahu yang dimiliki peserta didik lebih tinggi sehingga merupakan dorongan utama untuk menemukan sendiri pengetahuannya, dan pembelajaran akan bertahan lama dalam ingatan peserta didik, karena peserta didik tidak hanya dituntut menghafal fakta-fakta yang diberikan guru, tetapi peserta didik berusaha menemukan sendiri konsep melalui eksperimen dan pengamatan. Melalui metode Inquiry pelaksanaan pembelajaran akan menjadi lebih menyenangkan karena peserta didik belajar aktif berfikir secara kritis untuk menemukan konsep dari suatu masalah dengan menggunakan langkah-langkah tertentu yang didukung oleh data yang ada. Dengan metode Inquiry, peserta didik akan memproses pengalaman belajar sendiri dan mampu mengembangkan segenap potensi yang ada pada peserta didik itu sendiri dan akhirnya akan dapat mengembangkan ketiga aspek tuntutan pendidikan yakni kognitif, afektif, dan psikomotor, hal di atas sesuai dengan 
yang ditegaskan Wina (2008:196) yaitu metode Inquiry adalah, "Kegiatan pembelajaran yang menekankan pada proses berpikir secara kritis dan analitis untuk mencari dan menemukan sendiri jawaban dari suatu masalah yang dipertanyakan".

Guru adalah instrumen pembelajaran yang utama. Guru bukan hanya sebagai pengantar materi semata ataupun penyaji pelajaran, melainkan juga sebagai fasilitator terjadinya aktivitas belajar di kelas. Begitu pula dengan pengajaran yang efektif adalah pengajaran yang menyediakan kesempatan belajar sendiri bagi peserta didik atau melakukan aktivitas sendiri. Menurut Mulyadi (2002:17) Belajar merupakan suatau proses prubahan tingkah laku yang terjadi berdasarkan ada nya rangsangan dan respon, rangsangan tersebut berasal dari luar kemudian direspon. Tidak hanya perubahan tingkah laku saja tetapi juga dapat berupa keterampilan, dan peru ba han pada individu.

Hasil belajar adalah segala sesuatu yang dapat dilakukan atau dikuasai peserta didik sebagai hasil pembelajaran (Nasution 1999). Sedangkan menurut Sudjana (2002) Hasil belajar adalah kemampuan yang dimiliki peserta didik setelah ia menerima pengalaman belajarnya. Hasil belajar terwujud dalam perubahan tingkah laku dari tidak tahu menjadi tahu dan dari tdak mengeti menjadi mengerti. Hal ini sejalan dengan yang diungkapkan Arikunto;1992 yang menjelaskan bahwa” Tujuan penilaian hasil Belajar adalah untuk mengetahui apakah materi yang sudah diberika mudah dipa hami oleh peserta didik dan apakah metode yang digunakan sudah tepat atau belum.

IPA merupakan salah satu ilmu eksakta yang lahir dari pemikiran manusia secara terorganisir secara kritis dan sistematis sehingga dapat memberikan manfaat bagi kehidupan manusia dan lingkungannya. IPA merupakan salah satu mata pelajaran pokok di SD yang materinya berkesinambungan. Connant (dalam Usman, 2006:1) bahwa IPA adalah suatu deretan konsep serta skema konseptual yang berhubungan antara satu materi dengan materi lainnya yang tumbuh sebagai hasil eksperimentasi dan observasi.

Melalui metode Inquiry peserta didik dilatih kritis-kreatif untuk memecahkan masalahmasalah yang berhubungan dengan kehidupan sehari-hari, sehingga dapat lebih membuat peserta didik mampu untuk memecahkan masalah yang dihadapi dalam kehidupannya sesuai dengan yang ditegaskan Sapriya (2007:234) metode Inquiry adalah pembelajaran yang memfokuskan kepada pengembangan kemampuan peserta didik dalam berfikir reflektif dan kritis-kreatif. Metode Inquiry merupakan metode pembelajaran yang menempatkan peserta didik sebagai subjek belajar.

Metode Inquiry merupakan kegiatan pembelajaran yang mengembangkan kemampuan berfikir peserta didik secara sistematis, logis, kritis, dan analitis dengan memberikan pertanyaanpertanyaan dan mendapatkan jawaban atas dasar rasa ingin tahu. Metode Inquiry dilakukan untuk mencari dan menemukan sendiri jawaban dari suatu masalah yang dipertanyakan. Metode Inquiry mendorong peserta didik untuk menemukan sendiri pengetahuannya. Rasa ingin tahu yang dimiliki peserta didik akan mendorong mereka untuk melakukan penyelidikan. Lebih singkat Abu (2005:76) mengatakan metode Inquiry adalah penyelidikan. 
Peningkatan Hasil Belajar Peserta Didik pada Muatan IPA Melalui Metode Inquiry di Kelas VI SDN 155/X Kuala Dendang Semester Ganjil Tahun Ajaran 2021/2022, Agus Farichin

\section{METODE}

Jenis penelitian ini adalah penelitian tindakan kelas. Penelitian ini dilaksanakan di SDN 155/ X Kuala Dendang pada semester ganjil, tahun ajaran 2021/2022. Subjek dalam penelitian ini adalah siswa VI dengan jumlah peserta didik 8 orang. Prosedur penelitian ini meliputi perencanaan, pelaksanaan, pengamatan, dan refleksi. Penelitian ini dilaksanakan dalam dua siklus, masing-masing siklus terdiri dari dua kali pertemuan. Teknik yang digunakan dalam pengumpulan data adalah observasi, tes, catatan lapangan dan dokumentasi. Data dianalisis melalui persentase dan reduksi data.

\section{HASIL DAN DISKUSI}

\section{Siklus I}

\section{Perencanaan}

Jenis penelitian ini adalah penelitian tindakan kelas. Penelitian ini dilaksanakan di SDN 155/ X Kuala Dendang pada semester ganjil, tahun ajaran 2021/2022. Subjek dalam penelitian ini adalah siswa VI dengan jumlah peserta didik 8 orang. Prosedur penelitian ini meliputi perencanaan, pelaksanaan, pengamatan, dan refleksi. Penelitian ini dilaksanakan dalam dua siklus, masing-masing siklus terdiri dari dua kali pertemuan. Teknik yang digunakan dalam pengumpulan data adalah observasi, tes, catatan lapangan dan dokumentasi. Data dianalisis melalui persentase dan reduksi data.

\section{Pelaksanaan}

Pertemuan Peetama pada siklus 1 dilaksanakan pada hari Senin, tanggal 25 Oktober 2021 di kelas VI SDN 155/X Kuala Dendang. Setelah bel masuk berbunyi, seluruh peserta didik masuk ke lokal dan guru memeriksa kesiapan dan kerapian peserta didik. Bagi peserta didik yang pakaiannya belum rapi, guru menyuruh peserta didik untuk merapikan pakaiannya terlebih dahulu.

Pada kegiatan pendahuluan ini guru memberikan salam dan mengajak semua peserta didik berdo'a menurut agama dan keyakinan masing-masing. Menyanyikan lagu "Indonesia Raya" bersama-sama, dilanjutkan lagu Nasional "Tanah Airku”. Guru mengecek kesiapan diri peserta didik dengan mengisi lembar kehadiran dan memeriksa kerapihan pakaian, posisi tempat duduk disesuaikan dengan kegiatan pembelajaran. Pembiasaan literasi. Menginformasikan tema, sub tema, tujuan yang akan dicapai, dan langkah kegiatan. Guru menyampaikan tahapan kegiatan yang dilaksanakan meliputi kegiatan diskusi, tanya jawab pelaporan. Menyampaikan tehnik penilaian.

Pada kegiatan inti ini dilakukan penyajian materi oleh guru menggunakan peta konsep, dengan tujuan agar peserta didik dapat memahami peta konsep tentang perkembangan makhluk hidup. Dengan metode Inquiry guru menjelaskan materi menggunakan peta konsep. Peserta didik dapat memahami peta konsep tentang menganalisis cara tumbuhan menyesuaikan diri dengan lingkungannya (C2), selain itu dapat menyajikan karya cara tumbuhan menyesuaikan diri dengan lingkungannya (C6).

Pada pertemuan ini setiap peserta didik membaca teks tentang Bunga Teratai (literasi). Peserta didik secara berkelompok akan berpetualang di lingkungan sekolah. Guru telah menyiapkan 
beberapa pos. Pada setiap pos sudah tersedia berbagai jenis tumbuhan atau gambar tumbuhan beserta informasi tentang cara tumbuhan tersebut beradaptasi. Tugas setiap kelompok adalah mengumpulkan informasi sebanyak mungkin, mencatatnya, dan mendiskusikannya dalam kelompok. Guru meminta peserta didik memilih satu jenis tanaman dan membuat catatan tentang ciri tanaman tersebut serta bagaimana tanaman tersebut beradaptasi. Guru meminta peserta didik memilih satu jenis gambar hewan dan membuat catatan tentang cirinya tersebut serta bagaimana caranya beradaptasi. Peserta didik kemudian menulis laporan berdasarkan informasi pada peta pikiran. Peserta didik mempresentasikan/melaporkan hasil temuan mereka di depan kelas. Tugas dinilai dengan daftar periksa dan disosialisasikan kepada peserta didik. Peserta didik melakukan refleksi dengan menjawab pertanyaan yang terdapat dalam Buku Peserta didik. Guru dapat menambahkan pertanyaan refleksi berdasarkan panduan yang terdapat pada lampiran di Buku Guru.

Pada kegiatan penutup ini guru bersama-sama peserta didik membuat kesimpulan/ rangkuman hasil belajar selama sehari. Kemudian bertanya jawab tentang materi yang telah dipelajari (untuk mengetahui hasil ketercapaian materi). Guru memberi kesempatan kepada peserta didik untuk menyampaikan pendapatnya tentang pembelajaran yang telah diikuti. Lalu, melakukan penilaian hasil belajar. Mengajak semua peserta didik berdo'a menurut agama dan keyakinan masing-masing (untuk mengakhiri kegiatan pembelajaran).

Pertemuan kedua pada siklus 1 dilaksanakan pada hari Senin, tanggal 1 November 2021 di kelas VI SDN 155/X Kuala Dendang. Setelah bel masuk berbunyi, seluruh peserta didik masuk ke lokal dan guru memeriksa kesiapan dan kerapian peserta didik. Bagi peserta didik yang pakaiannya belum rapi, guru menyuruh peserta didik untuk merapikan pakaiannya terlebih dahulu.

Pada kegiatan pendahuluan ini guru memberikan salam dan mengajak semua peserta didik berdo'a menurut agama dan keyakinan masing-masing. Menyanyikan lagu "Indonesia Raya" bersama-sama, dilanjutkan lagu Nasional "Tanah Airku”. Guru mengecek kesiapan diri peserta didik dengan mengisi lembar kehadiran dan memeriksa kerapihan pakaian, posisi tempat duduk disesuaikan dengan kegiatan pembelajaran. Pembiasaan literasi. Menginformasikan tema, sub tema, tujuan yang akan dicapai, dan langkah kegiatan. Guru menyampaikan tahapan kegiatan yang dilaksanakan meliputi kegiatan diskusi, tanya jawab pelaporan. Menyampaikan tehnik penilaian.

Pada kegiatan inti ini dilakukan penyajian materi oleh guru menggunakan peta konsep, dengan tujuan agar peserta didik dapat memahami peta konsep tentang perkembangan makhluk hidup. Dengan metode Inquiry guru menjelaskan materi menggunakan peta konsep. Pada kegiatan inti ini dilakukan penyajian materi oleh guru menggunakan peta konsep, dengan tujuan agar peserta didik dapat memahami peta konsep tentang perkembangan makhluk hidup. Dengan metode Inquiry guru menjelaskan materi menggunakan peta konsep. Peserta didik dapat memahami peta konsep tentang menganalisis cara tumbuhan menyesuaikan diri dengan lingkungannya (C2), selain itu dapat menyajikan karya cara tumbuhan menyesuaikan diri dengan lingkungannya (C6). 
Setelah itu guru menunjukkan tanaman yang dibawanya (kangkung atau tanaman lainnya). Guru dapat meminta peserta didik untuk menulis pertanyaan terkait tumbuhan/sayuran yang mereka lihat terkait habitatnya. Setiap peserta didik mendiskusikan pertanyaan yang ditulisnya dalam kelompok. Guru berkeliling untuk memberikan bantuan saat peserta didik berdiskusi. Guru bisa memberikan pertanyaan pancingan apabila diskusi tidak berjalan lancar. Guru melakukan penilaian terhadap satu kelompok saat mereka berdiskusi. Saat menilai, guru menggunakan rubrik. Peserta didik yang belum dinilai pada kesempatan ini dapat dinilai saat mereka melakukan diskusi di kesempatan lain. Guru menginformasikan kepada peserta didik bahwa mereka akan belajar tentang ciri-ciri tumbuhan dan bagaimana mereka beradaptasi. Peserta didik memulai kegiatan dengan melakukan pengamatan gambar yang ada pada buku pelajaran dan membaca teksnya. Peserta didik melakukan diskusi setelahnya. Guru kembali berkeliling untuk memberikan motivasi. Peserta didik dapat menambah pengetahuan mereka dengan meminta mereka untuk membaca buku di perpustakaan atau teks yang telah disiapkan tentang cara tumbuhan beradaptasi di lingkungannya (apabila tersedia). Apabila tidak memiliki sumber tersebut, guru dapat mendatangkan nara sumber dari orang tua. Setelah mengamati tumbuhan di lingkungan sekolah, peserta didik mengisi diagram pada buku dan mendiskusikannya dalam kelompok. Guru memberikan dukungan dengan berkeliling dan mengajukan pertanyaan bantuan.

Pada kegiatan penutup ini guru bersama-sama peserta didik membuat kesimpulan/rangkuman hasil belajar selama sehari. Kemudian bertanya jawab tentang materi yang telah dipelajari (untuk mengetahui hasil ketercapaian materi). Guru memberi kesempatan kepada peserta didik untuk menyampaikan pendapatnya tentang pembelajaran yang telah diikuti. Lalu, melakukan penilaian hasil belajar. Mengajak semua peserta didik berdo'a menurut agama dan keyakinan masing-masing (untuk mengakhiri kegiatan pembelajaran).

\section{Observasi}

Pada akhir proses belajar mengajar peserta didik diberi tes formatif dengan tujuan untuk mengetahui tingkat keberhasilan peserta didik dalam proses belajar mengajar yang telah dilakukan. Adapun data hasil penelitian pada siklus I adalah sebagai berikut:

Tabel 1. Rekapitulasi Hasil Tes Formatif Pada Siklus I

\begin{tabular}{|c|c|c|}
\hline No & Uraian & Hasil \\
\hline 1 & Jumlah Nilai & 530 \\
\hline 2 & Rata-rata Nilai & 66.25 \\
\hline 3 & Peserta didik Tuntas & 5 \\
\hline 4 & Peserta didik Tidak Tuntas & 3 \\
\hline 5 & Persentase Peserta didik Tuntas & $63 \%$ \\
\hline 6 & Persentase Peserta didik Tidak Tuntas & $38 \%$ \\
\hline
\end{tabular}


Dari tabel di atas dapat dijelaskan bahwa dengan menerapkan model pembelajaran Inquiry diperoleh nilai rata-rata hasil belajar peserta didik adalah 66,25 dan ketuntasan belajar mencapai 63\% atau ada 5 peserta didik dari 8 peserta didik sudah tuntas belajar. Hasil tersebut menunjukkan bahwa pada siklus pertama secara klasikal peserta didik belum tuntas belajar, karena peserta didik yang memperoleh nilai sesuai KKM hanya sebesar 63\% lebih kecil dari persentase ketuntasan yang dikehendaki. Hal ini disebabkan karena peserta didik masih merasa baru dan belum mengerti apa yang dimaksudkan dan digunakan guru dengan menerapkan model pembelajaran Inquiry.

\section{Refleksi}

Berdasarkan hasil pengamatan atau observasi, maka dilakukan refleksi terhadap aktivitas dan hasil belajar peserta didik setiap pertemuan pada siklus I, refleksi dilaksanakan pada hari Jumat tanggal 5 November 2021 bersama seorang observer bernama Lusiyono, S.Pd. SD, dimana perolehan hasilnya belum mencapai KKM yang ditentukan, karena proses pembelajaran belum maksimal. Sesuai dengan hasil pengamatan aktivitas belajar peserta didik yang belum maksimal, mempengaruhi hasil belajar peserta didik dalam proses pembelajaran. Karena materi dipelajari dalam langkah-langkah metode yang digunakan hanya baru dua karakteristik aktivitas yang dikuasai oleh peserta didik yaitu mengidentifikasi topik dan merencanakan tugas yang akan dipelajari. Pada hal guru dalam kegiatan awal sudah melakukan tanya jawab dengan media untuk membuka skemata peserta didik, tetapi peserta didik belum maksimal menjawab pertanyaan guru baik pertemuan pertama maupun pertemuan kedua. Untuk itu pada siklus II guru akan memberikan hadiah kepada peserta didik yang mampu atau mendapatkan hasil belajar dengan baik. Untuk itu penelitian ini dilanjutkan ke siklus berikutnya.

\section{SIKLUS II}

\section{Perencanaan}

Persiapan yang dilakukan pada perencanaan siklus I adalah mempersiapkan silabus. Kemudian membuat Rencana Pelaksanaan Pembelajaran (RPP) siklus II yang bercirikan pembelajaran menggunakan metode Inquiry. Mempersiapkan bahan ajar, mempersiapkan media pembelajaran. Lalu, Mempersiapkan soal ulangan harian dan kunci jawaban, mempersiapkan hadiah. Dan terakhir mempersiapkan catatan lapangan siklus II.

\section{Pelaksanaan}

Pertemuan pertama pada siklus II dilaksanakan pada hari Senin tanggal 8 November 2021 di kelas VI SDN 155/X Kuala Dendang dengan materi pokok tentang Mengalisis cara makhlukhidup menyesuaikan diridengan lingkungan Menyajikan karya tentangcara makhluk hidupmenyesuaikan diri denganlingkungannya, sebagaihasil penelusuran berbagaisumber. Pertemuan pertama siklus II terdiri dari tiga tahapan kegiatan yaitu kegiatan pendahuluan, kegiatan inti dan kegiatan penutup.

Menginformasikan tema, sub tema, langkah pembelajaran dan tujuan pembelajaran yang akan dicapai Guru membuka pelajaran dengan mengucapkan salam pada peserta didik. Guru lalu mengabsen dan menanyakan kondisi peserta didik apakah kesehatan peserta didik baik-baik saja pada 
Peningkatan Hasil Belajar Peserta Didik pada Muatan IPA Melalui Metode Inquiry di Kelas VI SDN 155/X Kuala Dendang Semester Ganjil Tahun Ajaran 2021/2022, Agus Farichin

siang itu. Kemudian, guru melakukan apersepsi KD Mengalisis cara makhluk hidup menyesuaikan diridengan lingkungan Menyajikan karya tentangcara makhluk hidupmenyesuaikan diri denganlingkungannya, sebagaihasil penelusuran berbagai sumber.

Pada kegiatan inti ini dilakukan penyajian materi oleh guru menggunakan peta konsep, dengan tujuan agar peserta didik dapat memahami peta konsep tentang perkembangan makhluk hidup. Dengan metode Inquiry guru menjelaskan materi menggunakan peta konsep. Pada kegiatan inti ini guru mengaitkan pembelajaran sebelumnya dengan topik yang akan dibahas berikutnya dengan mengajukan pertanyaan berikut: Tahukah kamu bahwa ternyata hewan juga mempunyai strategi masing-masing dalam mempertahankan kehidupan mereka dan hal tersebut juga sangat erat kaitannya dengan tempat tinggal (habitat) mereka?. Lalu, guru mengajak peserta didik mencari tahu lebih lanjut tentang tumbuhan. Apakah kamu pernah mengamati berbagai jenis tumbuhan disekitarmu?, Peserta didik diminta untuk mengetahui cara perkembangbiakannya. Peserta didik diminta mendiskusikan jawaban mereka secara berpasangan. Peserta didik diminta menuliskan dan membandingkan hasil diskusi mereka pada buku masing-masing. Siwa diminta menuliskan hasil analisis mereka tentang cara perkembangbiakannya. Kemudian guru bertanya: Apakah kamu pernah mengamati bebek berenang di kolam?, Mengapa bebek dapat berenang dengan baik?, Peserta didik diminta membaca teks tentang bebek dalam hati. Kemudian setelah itu, peserta didik diberi tugas mengamati tiga hewan yang mereka bawa dari rumah atau hewan yang ada di sekitar peserta didik. Lalu, berdasarkan pengamatan, peserta didik diminta membandingkancara perkembangbiakannya. Peserta didik diminta menulis laporan berdasarkan pengamatan mereka pada tabel yang terdapat di buku peserta didik.

Pada kegiatan penutup ini guru bersama-sama peserta didik membuat kesimpulan/rangkuman hasil belajar selama sehari. Bertanya jawab tentang materi yang telah dipelajari (untuk mengetahui hasil ketercapaian materi). Guru memberi kesempatan kepada peserta didik untuk menyampaikan pendapatnya tentang pembelajaran yang telah diikuti. Melakukan penilaian hasil belajar. Lalu, mengajak semua peserta didik berdo'a menurut agama dan keyakinan masing-masing (untuk mengakhiri kegiatan pembelajaran).

Pertemuan kedua pada siklus II dilaksanakan pada hari Senin, tanggal 15 November 2021 di kelas VI SDN 155/X Kuala Dendang. Pada pertemuan ini materi yang dibahas mengenai keseimbangan ekosistem dengan topic bahasana mengenai berbagai kegiatan manusia yang dapat mempengaruhi keseimbangan ekosistem. Perteman kedua terdiir dari tiga tahapan kegiatan yaitu pendahuluan, inti dan penutup.

Menginformasikan tema, sub tema, langkah pembelajaran dan tujuan pembelajaran yang akan dicapai Guru membuka pelajaran dengan mengucapkan salam pada peserta didik. Guru lalu mengabsen dan menanyakan kondisi peserta didik apakah kesehatan peserta didik baik-baik saja pada siang itu. Kemudian, guru melakukan apersepsi KD Mengalisis cara makhluk hidup menyesuaikan diridengan lingkungan Menyajikan karya tentangcara makhluk hidupmenyesuaikan diri denganlingkungannya, sebagaihasil penelusuran berbagai sumber. 
Pada kegiatan inti ini dilakukan penyajian materi oleh guru menggunakan peta konsep, dengan tujuan agar peserta didik dapat memahami peta konsep tentang perkembangan makhluk hidup. Dengan metode Inquiry guru menjelaskan materi menggunakan peta konsep. Pada kegiatan inti ini Setelah membaca teks, peserta didik diminta menjawab pertanyaan yang terdapat di buku peserta didik. Peserta didik diminta menuliskan cara Hyena mempertahankan diri dan wilayahnya. Kemudian, peserta didik diminta menuliskan perbedaan Hyena dengan hewan lainnya dalam mengatasi masalah. Setelah itu, peserta didik menuliskan kesimpulan mereka tentang isi bacaan. Setelah menjawab pertanyaan berdasarkan teks, peserta didik diajak mencari tahu bagaimana cara hewan lain beradaptasi. Peserta didik diminta mengamati gambar dan membaca teks dan tentang adaptasi hewan, di antaranya kamuflase, mimikri, melepas bagian tubuh, menggulungkan diri. Selanjutnya, peserta didik diminta mencari tahu bagaimana cumi-cumi, walang sangit, dan siput beradaptasi dengan lingkungannya. Peserta didik diminta menulis kesimpulan tentang adaptasi hewan menggunakan peta pikiran. Peserta didik menuliskan cara perkembangbiakan hewan yang ada disekitarnya. Peserta didik mempresentasikannya di depan kelas. Peserta didik memperhatikan gambar yang dipanjang guru mengenai berbagi jenis tumbuhan. Peserta didik melakukan tanya jawab dan diskusi mengenai tumbuhan tersebut. Peserta didik menyebutkan cara perkembangbiakan tumbuhan dan cara adaptasi tumbuhan. Peserta didik membuat tabel dan menjelaskannya di depan kelas. Peserta didik melakukan perenungan dengan menjawab pertanyaan yang terdapat dalam buku peserta didik. Guru dapat menambahkan pertanyaan perenungan berdasarkan panduan yang terdapat pada lampiran di buku guru.

Pada kegiatan penutup ini guru bersama-sama peserta didik membuat kesimpulan / rangkuman hasil belajar selama sehari. Bertanya jawab tentang materi yang telah dipelajari (untuk mengetahui hasil ketercapaian materi). Guru memberi kesempatan kepada peserta didik untuk menyampaikan pendapatnya tentang pembelajaran yang telah diikuti. Melakukan penilaian hasil belajar. Lalu, mengajak semua peserta didik berdo'a menurut agama dan keyakinan masing-masing (untuk mengakhiri kegiatan pembelajaran).

\section{Observasi}

Pada akhir proses belajar mengajar peserta didik diberi tes formatif II dengan tujuan untuk mengetahui tingkat keberhasilan peserta didik selama proses belajar mengajar yang telah dilakukan. Instrumen yang digunakan adalah tes formatif II. Adapun data hasil penelitian pada siklus II adalah sebagai berikut.

Tabel 2. Rekapitulasi Hasil Tes Formatif Pada Siklus II

\begin{tabular}{|c|c|c|}
\hline No & Uraian & Hasil \\
\hline 1 & Jumlah Nilai & 590 \\
\hline 2 & Rata-rata Nilai & 73.75 \\
\hline 3 & Peserta didik Tuntas & 7 \\
\hline 4 & Peserta didik Tidak Tuntas & 1 \\
\hline 5 & Persentase Peserta didik Tuntas & $88 \%$ \\
\hline 6 & Persentase Peserta didik Tidak Tuntas & $13 \%$ \\
\hline
\end{tabular}


Dari tabel di atas diperoleh nilai rata-rata hasil belajar peserta didik adalah 73,75 dan ketuntasan belajar mencapai $88 \%$ atau ada 7 peserta didik dari 8 peserta didik sudah tuntas belajar. Hasil ini menunjukkan bahwa pada siklus II ini ketuntasan belajar secara klasikal telah mengalami peningkatan lebih baik dari siklus I. Adanya peningkatan hasil belajar peserta didik ini karena setelah guru menginformasikan bahwa setiap akhir pelajaran akan selalu diadakan tes sehingga pada pertemuan berikutnya peserta didik lebih termotivasi untuk belajar. Selain itu peserta didik juga sudah mulai mengerti apa yang dimaksudkan dan dinginkan guru dengan menerapkan model pembelajaran Inquiry.

\section{Refleksi}

Berdasarkan hasil pengamatan (observasi) peneliti dengan observer dapat didiskripsikan bahwa pelaksanaan pembelajaran IPA dengan menggunakan metode Inquiry pada siklus VI dapat meningkatkan hasil belajar peserta didik dalam kategori baik. Kegiatan refleksi dilaksanakan pada hari jumat tanggal 19 November 2021 bersama seorang observer bernama Lusiyono,S.Pd. SD.Berdasarkan refleksi tersebut, diharapkan kepada guru di SDN 155/X Kuala Dendang dapat menerapkan metode ini dalam proses pembelajaran agar hasil yang dicapai lebih maksimal. Peneliti mengakhiri penelitian ini dengan perolehan hasil hanya baik. Karena hasil yang diperoleh sudah melebihi Kriteria Ketuntasan Minimal yaitu 75\%. Hal ini sesuai dengan pendapat Suharsimi (2006:55) "bahwa standar ketuntasan pembelajaran adalah 75\%. Jadi diharapkan keberhasilan yang dicapai adalah 75\%, jika belum berhasil maka siklus diteruskan sampai berhasil 75\%." Disamping itu karena keterbatasan waktu peneliti dalam melakukan penelitian. Namun PTK ini akan dapat berlanjut untuk perbaikan proses pembelajaran yang lebih baik.

\section{Diskusi}

Selama pembelajaran berlangsung tidak semua peserta didik mencapai tingkat penguasaan materi yang memuaskan, bahkan banyak yang gagal dalam pembelajaran. Untuk itu penulis melakukan perbaikan untuk mata pelajaran IPA yaitu tentang konsep yang dikuasai cepat hilang dari ingatannya. Peserta didik kurang terlibat dalam pembelajaran. Rendahnya tingkat penguasaan peserta didik terhadap materi pelajaran. Peserta didik tidak bisa atau tidak mau menjawab pertanyaan guru. Selain itu peserta didik pasif dalam pembelajaran.

Hasil belajar mata pelajaran IPAmelalui metode inquiry pada setiap siklusnya, terlihat pada siklus ke 2 pembelajaran dapat tuntas atau berhasil $88 \%$. Semua peserta didik sudah menguasai materi pelajaran. Peserta didik sudah dapat menjawab pertanyaan guru yang diajukan secara individu maupun klasikal. Selain itu sudah ada peserta didik yang mau bertanya tentang materi pelajaran yang belum dimengerti. Bahkan ada peserta didik yang sudah dapat menanggapi pertanyaan dari temannya. Berarti sumua hal menjadi tujuan dari perbaikan pembelajaran sudah tercapai semua. Dalam hal ketuntasan pada siklus 1 meningkat menjadi 63\%. Pada siklus ke 2 meningkat dengan tajam yaitu 
persentase ketuntasan belajarnya mencapai $88 \%$. Hal ini sesuai dengan pendapat Haury (dalam Iwan 2008:1) yang menyatakan,"Metode Inquiry berkaitan dengan aktifitas dan keterampilan aktif yang fokus kepada pencarian pengetahuan atau pemahaman untuk memuaskan rasa ingin tahu." Dari penjelasan di atas jelas bahwa metode Inquiry merupakan suatu teknik atau cara dimana peserta didik mampu menemukan sendiri jawaban dari sebuah masalah yang ditemui dalam pembelajaran melalui penelitian atau penyelidikan.

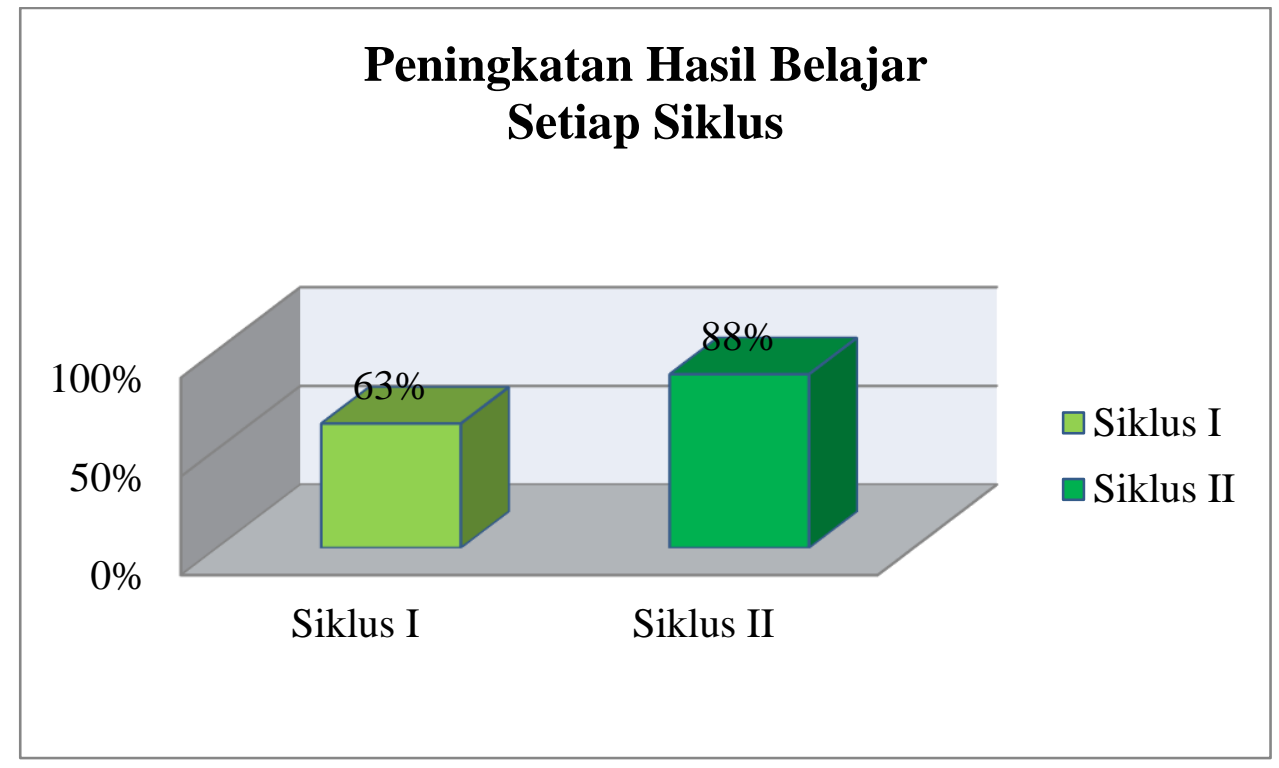

Gambar 1. Peningkatan Hasil belajar Setiap Siklus

\section{KESIMPULAN}

Dari hasil perbaikan pembelajaran yang dilakukan selama 2 siklus, maka dapat disimpulkan bahwa Tingkat penguasaan peserta didik terhadap materi pelajaran dapat meningkat karena guru selalu menggunakan metode Inquiry. Peningkatan terjadi dalam hal hasil belajar peserta didik maupun persentase ketuntasan secara klasikal. Sedangkan dalam hal ketuntasan belajar pada siklus 1 ketuntasan hasil belajar sebesar $63 \%$ meningkat pada siklus ke 2 yaitu persentase ketuntasan belajarnya mencapai $88 \%$.

Dengan adanya laporan ini akan dapat memberikan masukan kepada semua pendidik dan oleh sebab itu biasakanlah selalu melakukan perbaikan pembelajaran dalam pembelajaran dengan rasa tanpa pamrih demi peningkatan kualitas pendidikan dimasa mendatang dan bekerja samalah dengan seluruh warga sekolah terutama pendidik dan peserta didik. Untuk menindaklanjuti perbaikan ini, penulis menyampaikan beberapa saran perlu yang dapat dilakukan yaitu: melakukan perbaikan pembelajaran setiap menemui kegagalan dalam pembelajaran. Kerja sama dengan teman sejawat untuk merancang dan memecahkan masalah yang ada. Kemudian merangkul teman yang seprofesi serta terus mensosialisasikan dalam bermacam kegiatan dan forum seperti waktu kegiatan Kelompok Kerja Guru. (KKG), untuk memecahkan masalah yang tidak dapat teratasi dengan perbaikan pembelajaran. Gunakan selalu alat peraga dalam setiap pembelajaran, gunakan selalu metode yang 
Peningkatan Hasil Belajar Peserta Didik pada Muatan IPA Melalui Metode Inquiry di Kelas VI SDN 155/X Kuala Dendang Semester Ganjil Tahun Ajaran 2021/2022, Agus Farichin

tepat agar pembelajaran beralangsung kondusif. Jangan kikir terhadap pujian kepada peserta didik supaya peserta didik selalu termotivasi untuk mengikuti pelajaran dengan baik.

\section{REFERENSI}

A.M Sardiman. 2009. Interaksi dan Motivasi Belajar Mengajar. Jakarta: PT. Rajawali. Pers.

Agung, Iskandar. 2012. Panduan Penelitian Tindakan Kelas bagi Guru. Jakarta: Bestari Buana Murni. Arikunto, Suharsimi. 1992. Prosedur Penelitian Suatu Pendekatan Praktik. Jakarta: Rineka Cipta.

BNSP. 2006. Kurikulum Tingkat Satuan Pendidikan. Jakarta: Depniknas.

Darsono. 2001. Belajar dan Pembelajaran. Semarang: IKIP Semarang Press.

Husain Usman, 2006, Metodologi Penelitian Sosial, Jakarta: Bumi. Aksara.

Mansjoer, Arif dkk. 2005. Kapita Selekta Kedokteran Edisi ketiga Jilid 1 Cetakan keenam. Jakarta: Media Aesculapius Fakultas Kedokteran UI

Masnur Muslich, 2008. KTSP Pembelajaran Berbasis Kompetensi dan Kontekstual. Jakarta: Bumi Aksara

Mulyadi, 2002, Auditing, Edisi keenam, Cetakan pertama, Jakarta: Salemba

Nana Sudjana. 2002. Penilaian Hasil Proses Belajar Mengajar. Bandung: PT Remaja Rosdajarya.

Nana Syaodih Sukmadinata, 2005, Landasan Psikologi Proses Pendidikan. Bandung: PT Rosda Karya.

Nasution, S., 1999, Kurikulum dan Pengajaran, Jakarta: Bumi Aksara, cet-ke-3.

Oemar Hamalik.2008. Kurikulum Dalam Pembelajaran. Jakarta: Bumi Aksara

Rusman. 2010. Model-model Pembelajaran Mengembangkan ProfesionalismeGuru. Jakarta: PT Raja Grafindo Persada

Sapriya, dkk. 2007. Pengembangan IPS di SD. Bandung: UPI PRESS.

Wina Sanjaya. 2007. Strategi Pembelajaran Berorientasi Standar Proses Pendidikan. Jakarta: Kencana Prenada Media Group.

Winkel, W. S. 2004. Psikologi Pendidikan dan Evaluasi Belajar. Jakarta: PT. Gramedia Pustaka Utama. 